\title{
Influence of Amazon and Orinoco offshore surface water plumes on oligotrophic bacterioplankton diversity in the west tropical Atlantic
}

\author{
Ian Hewson ${ }^{1,2, *}$, Douglas G. Capone ${ }^{1}$, Joshua A. Steele ${ }^{1}$, Jed A. Fuhrman ${ }^{1}$ \\ ${ }^{1}$ Department of Biological Sciences and Wrigley Institute for Environmental Studies, University of Southern California, \\ 3616 Trousdale Pkwy AHF 107, Los Angeles, California 90089-0371, USA \\ ${ }^{2}$ Present address: Department of Ocean Sciences, University of California Santa Cruz, 1156 High Street EMS D446, \\ Santa Cruz, California 95064 USA
}

\begin{abstract}
The Amazon and Orinoco River low-salinity plumes extend $>200 \mathrm{~km}$ eastwards into the west tropical Atlantic Ocean and Caribbean Sea; combined, they have the greatest discharge of fresh water and suspended sediments to oceans worldwide. However, their impacts upon bacterioplankton assemblages have not been previously described. We investigated bacterioplankton assemblage composition using a sensitive DNA fingerprinting technique - automated rRNA intergenic spacer analysis (ARISA) - over vertical profiles from surface waters to $1200 \mathrm{~m}$ depth. Bacterioplankton fingerprint richness and diversity were lowest immediately below the plume at $40 \mathrm{~m}$, but at all other depths were statistically indistinguishable. Surface water bacterial production was significantly and negatively correlated with salinity $(r=-0.805, \mathrm{p}<0.001, \mathrm{n}=22)$, and fingerprint Simpson's Reciprocal Index (diversity) and the total number of operational taxonomic units (OTU) per fingerprint (richness) were significantly correlated to bacterioplankton production $(\mathrm{r}=0.52$ and 0.74 , respectively, $\mathrm{p}<0.05, \mathrm{n}=22$ ), but not to other measured environmental parameters. In both plume and non-plume oceanic waters, assemblages were dissimilar at surface and $40 \mathrm{~m}$, suggesting different selection for taxa occurs vertically at these depths, irrespective of productivity and irradiance. Furthermore, there was no clear relationship between surface water assemblages located within plume waters and those experiencing more oceanic conditions, despite apparently distinct occurrence of certain common ( $>1 \%$ of fingerprint total amplified DNA fluorescence) OTUs in plume, intermediate plume and oceanic conditions. The inconsistency of total assemblage composition within surface plume waters demonstrates that assemblage composition is not tied directly to salinity but possibly to rapid microbial cycling and mixing of assemblages within small water masses. Moreover, our results demonstrate that the Amazon and Orinoco River offshore plumes have significant effects upon surface and underlying water bacterioplankton production in adjacent tropical waters.
\end{abstract}

KEY WORDS: Bacteria $\cdot$ Biogeography $\cdot$ Amazon $\cdot$ ARISA $\cdot$ Resource

Resale or republication not permitted without written consent of the publisher

\section{INTRODUCTION}

Bacterioplankton plays an important role in the marine microbial food web, consuming up to $50 \%$ of primary production (Fuhrman \& Azam 1980, 1982, Azam et al. 1983, Fuhrman 1992, Azam 1998), comprising up to $70 \%$ of biogenic $\mathrm{C}$ in oligotrophic marine surface waters (Fuhrman et al. 1989) and mediating most important elemental cycles in the marine environment (Zehr \& Ward 2002). Since the advent of molecular tools for addressing microbial diversity in marine plankton (Giovannoni et al. 1990, Schmidt et al. 1991, Fuhrman et al. 1992, Fuhrman \& Ouverney 1998, De Long 2002), numerous studies have elucidated metabolic pathways not previously recognized in marine plankton (Beja et al. 2000, Zehr et al. 2000, Kol- 
ber et al. 2001, Palenik et al. 2003, Kuypers et al. 2005), necessitating opening of the 'black box' of bacteria in biogeochemical models of nutrient cycling. There have been few studies examining ecological factors shaping whole bacterioplankton communities in the marine environment (Crump et al. 1999, Hollibaugh et al. 2000, Moeseneder et al. 2001, Troussellier et al. 2002, Stepanauskas et al. 2003, Hewson \& Fuhrman 2004), with most studies examining diversity on small spatial scales to determine total genetic richness (Giovannoni et al. 1990, Acinas et al. 1997, Acinas et al. 2004, Venter et al. 2004).

Bacterioplankton assemblage composition is believed to be influenced by combinations of bottom-up controlling factors, such as resource availability and quality (and consequently productivity) (Torsvik et al. 2002, Hewson et al. 2003, Horner-Devine et al. 2003), antagonistic interactions between component taxa (Long \& Azam 2001), and top-down controlling factors, such as bacterivory (Šimek et al. 2001) and viral lysis (Fuhrman \& Suttle 1993, Thingstad \& Lignell 1997); however, the magnitude, strength and interplay of these factors are not, as yet, fully understood.

River flow along most continental margins is localized to continental shelves, where rapid phytoplankton assimilation and denitrification prevent penetration of nutrients into oligotrophic currents or gyres (Nittrouer \& DeMaster 1996). However, several rivers with extremely large freshwater discharge penetrate neritic waters into central gyres and basins. Neritic phytoplankton take up some dissolved nutrients from input waters and subsequently settle out (DeMaster et al. 1996); however, dissolved organic matter persists within low-salinity offshore plumes. Because river plumes have low salinity, they are resistant to mixing and diffusion and thus diffuse slowly over 100s to 1000s of km (Ryther et al. 1967, Nittrouer \& DeMaster 1996).

The Amazon River has the highest freshwater discharge on earth, discharging $175000 \mathrm{~m}^{3} \mathrm{~s}^{-1}$ into the North Atlantic Ocean (Lerman 1980), approximately 5 times more freshwater than the next largest river system (Congo River). Like all rivers worldwide, the concentration of dissolved organic carbon (DOC) and trace elements (e.g. Fe) in the Amazon River is higher than in surface oceanic waters (Aucour et al. 2003). While bacterioplankton in the tributaries of the Amazon River have been demonstrated to be P-limited (Farjalla et al. 2002), phytoplankton in the coastal receiving waters are strongly N-limited (Ryther et al. 1967, DeMaster et al. 1996). Additionally, particle concentrations within the plume discharge into coastal waters at $>250 \times 10^{2} \mathrm{t} \mathrm{s}^{-1}$, (Nittrouer \& DeMaster 1996) settle out within ca. $100 \mathrm{~km}$ of the river mouth (DeMaster et al. 1996). Light limitation induced by suspended particles is alleviated offshore, and as a consequence, dense phytoplankton blooms form in pelagic waters (DeMaster et al. 1996). These blooms are then advected laterally by the North Brazil current. This feature is a northwards, fast $\left(>75 \mathrm{~cm} \mathrm{~s}^{-1}\right)$ moving, 100 to $200 \mathrm{~km}$ wide current (Flagg et al. 1986), which causes the Amazon River plume to extend offshore $>200 \mathrm{~km}$ into the North Atlantic Ocean and Caribbean Sea (Hellweger \& Gordon 2002). Thus, the organic matter rich Amazon River and nearby Orinoco River may have significant impacts upon the ecology of the western tropical Atlantic, since receiving waters are typically oligotrophic and strongly nutrient limited.

Several studies have examined the impact of lowsalinity offshore plumes upon the ecology of microorganisms in surrounding waters. A study of eukaryotic and prokaryotic phytoplankton diversity by $r b c L$ gene expression in the Mississippi River plume (Gulf of Mexico) indicated substantial impact of low-salinity waters upon community composition (Wawrik et al. 2003). Another study found significant negative impacts of increasing salinity on microzooplankton grazing in the Mississippi River plume, yet net positive impacts upon rates of bacterivory (Jochem 2003). Conversely, the Amazon River plume water had no significant impact upon bacterial abundance, production or phytoplankton biomass when advected into oligotrophic waters near Barbados (Choi et al. 2001). A. Subramaniam et al. (unpubl.) have found that the Amazon River can have a strong influence on the composition of offshore $\mathrm{N}_{2}$ fixing populations. To the best of our knowledge, there have been no previous studies examining bacterioplankton assemblage composition in offshore river plumes.

The aim of this study was to examine whether the Amazon and Orinoco River plumes influence bacterioplankton assemblage composition and production, and whether differences were related to specific environmental parameters controlling overall productivity. We hypothesized that bacterioplankton assemblage diversity may be coupled to production, since previous studies have indicated inverted U-shaped distributions between these parameters over productivity gradients (Horner-Devine et al. 2003, Hewson \& Fuhrman 2004). Vertical profiles of bacterioplankton assemblage composition were obtained using a highthroughput molecular fingerprinting method (automated rRNA intergenic spacer analysis, ARISA) (Fisher \& Triplett 1999), and compared to physical and chemical parameters. Moreover, this study aimed to determine possible factors controlling bacterioplankton assemblage composition in the presence of strong vertical and lateral spatial gradients in the oligotrophic ocean. 


\section{MATERIALS AND METHODS}

Sampling locations. Bacterioplankton assemblage DNA was collected aboard the RV 'Seward Johnson' in April/May 2003 at a total of 26 stations in the tropical western Atlantic (Fig. 1). Seawater was collected using Niskin bottles mounted on a CTD array at the surface ( $\mathrm{n}=26$ casts) $40(\mathrm{n}=10), 100(\mathrm{n}=4), 150(\mathrm{n}=12), 500$ $(\mathrm{n}=4), 800(\mathrm{n}=1), 1000(\mathrm{n}=5)$ and $1200 \mathrm{~m}(\mathrm{n}=1)$; however, not every depth was sampled on every cast due to time and equipment limitations. Parameters determined using the CTD array included temperature, salinity, beam attenuation, and dissolved $\mathrm{O}_{2}$ concentration. Additionally, bacterioplankton production and abundance were determined in the same samples (see method below).

Collection of bacterioplankton DNA. Seawater samples were drained immediately after collection into acidwashed and seawater-rinsed 4.51 polycarbonate bottles or 201 low-density polyethylene cubitainers, which were capped and maintained at ambient surface seawater temperature and $25 \%$ attenuated irradiance in a flowthrough on deck incubator until processing (within $2 \mathrm{~h}$ of collection). Surface seawater samples were filtered serially through $47 \mathrm{~mm}$ A/E Glass Fiber (Pall Gelman, $1.2 \mu \mathrm{m}$ nominal pore size) filters then through $0.22 \mu \mathrm{m}$ Sterivex-GV (Millipore) capsule filters using a peristaltic pump. Deep samples which required a greater volume (20 l) to obtain sufficient DNA for analysis were filtered serially through $142 \mathrm{~mm}$ diameter A/E filters onto $142 \mathrm{~mm}$ diameter $0.2 \mu \mathrm{m}$ Durapore filters using a polycarbonate positive pressure filter holder. Between samples, the manifolds were rinsed with $10 \% \mathrm{HCl}$ and de-ionised $\mathrm{H}_{2} \mathrm{O}$. After filtration, A/E filters and Durapore filters/Sterivex capsule filters were placed into sterile Whirl-pak bags and frozen at $-80^{\circ} \mathrm{C}$ prior to analysis at the University of Southern California, Los Angeles, USA.

Bacterioplankton production measurement. Bacterioplankton production was estimated by ${ }^{3} \mathrm{H}$-leu uptake (Simon \& Azam 1989). Seawater samples $(10 \mathrm{ml})$ were collected into triplicate sterile, seawater rinsed $15 \mathrm{ml}$ centrifuge tubes and inoculated with 8.6 $\mu \mathrm{Ci}{ }^{3} \mathrm{H}$-leu (5 nM final concentration, which was confirmed to saturate uptake in a separate incubation by addition of 0 to $10 \mathrm{nM}$ leu). One replicate was killed immediately by addition of $5 \%$ formalin. After $1 \mathrm{~h}$ incuba- tion in a flow-through outdoor incubator at $25 \%$ attenuated surface irradiance, samples were filtered through $25 \mathrm{~mm}$ Millipore Type HA $0.45 \mu \mathrm{m}$ filters, and proteins extracted by addition of ice-cold $5 \%$ trichloroacetic acid (TCA) and incubation for 2 min on the filtration manifold. After extraction, TCA was filtered through membranes, the filter washed repeatedly with TCA, then placed into $6 \mathrm{ml}$ scintillation vials containing $5 \mathrm{ml}$ Ultima Gold scintillation fluid. After incubating vials for $2 \mathrm{~h}$ at room temperature to allow clearing of filter membranes in scintillation fluid, radiolabel incorporation was measured in a BeckmanCoulter LS6500 scintillation counter. We used a con-

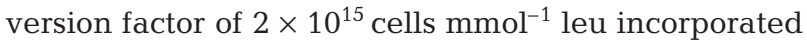
(Simon \& Azam 1989) to estimate bacterial production.

Bacterioplankton abundance measurement. Bacterial abundance was determined using SYBR Green I epifluorescence microscopy (Noble \& Fuhrman 1998). Seawater $(50 \mathrm{ml})$ was preserved from each depth with $2 \% 0.02 \mu \mathrm{m}$-filtered formaldehyde, and kept cold and in the dark until processing, which occurred within $12 \mathrm{~h}$ of collection. Sample volumes of 1 to $20 \mathrm{ml}$ (depending on depth) were filtered through $0.02 \mu \mathrm{m}$ $\mathrm{Al}_{2} \mathrm{O}_{3}$ Anodisc filters (Whatman) then dried on tissue paper, and stained on a $100 \mu \mathrm{l}$ drop of 1:2500-diluted SYBR Green I for $15 \mathrm{~min}$ in darkness. After staining, filters were re-dried and placed on a glass microscope

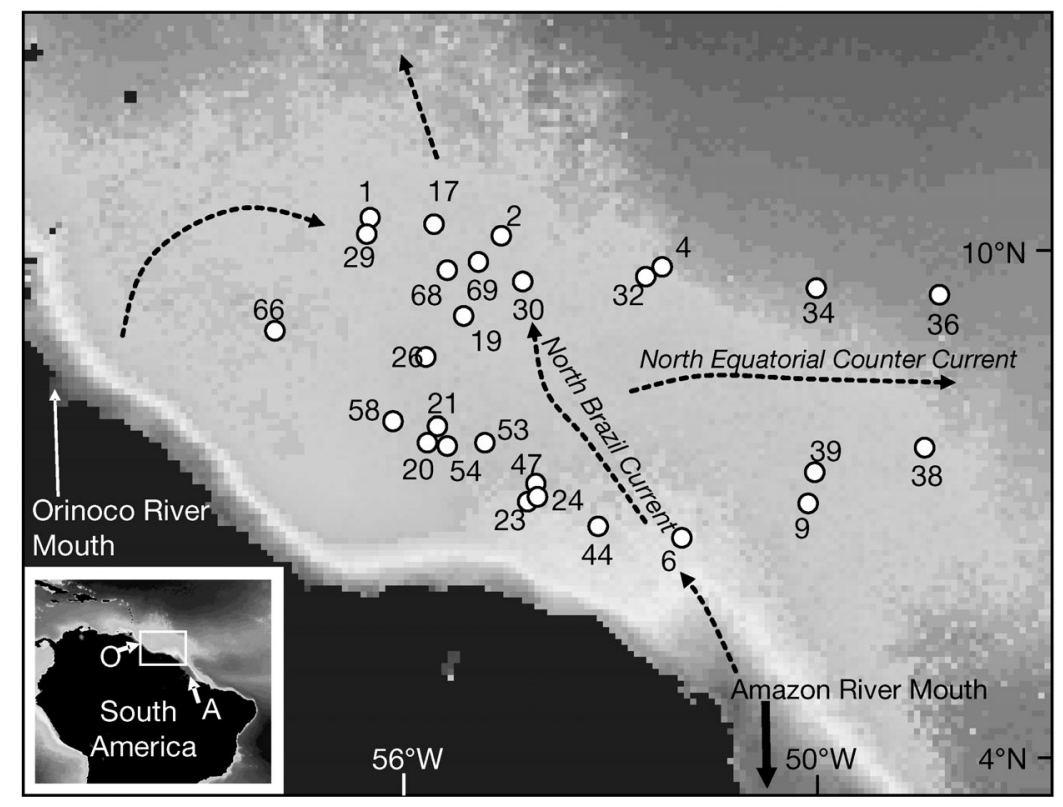

Fig. 1. Sampling stations in the tropical west Atlantic in April-May 2003. The background is a 2 yr mean of chl a concentration in surface waters (SeaWiFS). Lighter hues of grey indicate higher chl a concentrations (i.e. river plume) while darker areas indicate more oceanic waters. The location of the Orinoco River Mouth (O) and Amazon River Mouth (A) are given on the inset. Dominant currents are indicated by dashed arrows. Information on water movement from Goni \& Johns (2001) 
slide with $30 \mu \mathrm{l}$ of antifade (50:50:0.1 glycerol:phosphate buffered saline:[1:10 diluted $p$ :phenylenediamine]). Slides were frozen at $-20^{\circ} \mathrm{C}$ and stored until analyzed. They were then observed under blue light excitation on an Olympus BH-60 microscope at 1000x magnification. More than 200 bacterial cells were counted in 20 fields.

Assemblage DNA extraction and fingerprinting. Microbial DNA was extracted by heat/detergent lysis, phenol/chloroform purification and ethanol precipitation (Fuhrman et al. 1988). Sterivex capsule filters were capped with sterile leur-lock and syringe fittings and heat/detergent lysis occurred entirely within the capsule. After final ethanol precipitation, DNA extracts were quantified using the Pico Green dsDNA assay (Molecular Probes) in a Stratagene MX-3000 quantitative PCR thermocycler/fluorometer, then diluted to $2.5 \mathrm{ng}^{-1} \mathrm{l}^{-1}$.

ARISA was conducted on $10 \mathrm{ng}$ extracted DNA. PCR was carried out in $50 \mu \mathrm{l}$ reactions containing $1 \mathrm{X}$ PCR buffer, $2.5 \mathrm{mM} \mathrm{MgCl}_{2}, 1.25 \mathrm{mM}$ dNTPs (Promega PCR Nucleotide Mix), $0.8 \mu \mathrm{M}$ each of universal primer 1392 F (5'-G(C/T)ACACACCGCCCGT-3') and bacterialspecific 23S-115R (5'-GGGTT (C/G/T)CCCCATTC (A/G)G-3'), labeled with a $5^{\prime}$-TET phosphoramidite (Fisher \& Triplett 1999), BSA (40 $\mathrm{ng} \mathrm{pl}^{-1}$ final concentration; Sigma \# 8350) and 2.5 U Taq DNA polymerase (Promega) (Hewson \& Fuhrman 2004). Thermocycling in a Perkin Elmer 9600 comprised an initial 'hot start' at $95^{\circ} \mathrm{C}$ for $3 \mathrm{~min}$, followed by 30 cycles of denature at $95^{\circ} \mathrm{C}$ for $30 \mathrm{~s}$, anneal at $55^{\circ} \mathrm{C}$ for $30 \mathrm{~s}$ and extend at $72^{\circ} \mathrm{C}$ for $45 \mathrm{~s}$, and a final extension step of 7 min at $72^{\circ} \mathrm{C}$. PCR products were purified using Clean \& Concentrator-5 Kits (Zymo Research) to remove primers and salts. Amplicons were then quantified again using the Pico Green dsDNA assay and diluted to $5 \mathrm{ng}^{\mathrm{l}^{-1}}$. Purified products were electrophoresed on an ABI 377XL automated sequencer with custom-made FAMlabeled $1500 \mathrm{bp}$ standards (Bioventures) (AvanissAghajani et al. 1994). Sequencer gels were analysed using ABI Genescan software, and analysis outputs transferred to Microsoft Excel for subsequent processing.

Statistical analysis of assemblage DNA fingerprints. Fragments less than 5 times baseline fluorescence in height were eliminated since they could not be distinguished from instrument 'noise'. With these criteria, an operational taxonomic unit (OTU) exceeded the baseline when it contributed $>0.09 \%$ of total amplified DNA fluorescence (Hewson \& Fuhrman 2004). The area under each peak was then expressed as a percentage of the total integrated area under the electropherogram. Simpson's reciprocal index $(D)$ was calculated manually (Legendre \& Legendre 1998) according to:

$$
D=\left[\sum_{i=1}^{n}\left(P_{i}\right)^{2}\right]^{-1}
$$

where $P_{i}$ is the fraction of each peak of total integrated area. Whole assemblages (i.e. all OTU each comprising $>0.09 \%$ of total amplified DNA) were compared by calculating Whittaker's (1952) index of association $\left(S_{w}\right)$ using:

$$
S_{w}=1-\sum_{i=1}^{n} \frac{\left|\left(b_{i 1}-b_{i 2}\right)\right|}{2}
$$

where $b_{i 1}$ and $b_{i 2}$ are the percentage of total amplified DNA fluorescence of the ith OTU in samples 1 and 2, respectively. $S_{W}$ scales from 0 (completely dissimilar fingerprints) to 1 (identical fingerprints).

To account for variability in size associated with standards, ARISA fingerprints were binned using windows of $\pm 1 \mathrm{bp}$ from 400 to $700 \mathrm{bp}, \pm 2 \mathrm{bp}$ from 700 to $1000 \mathrm{bp}$ and $\pm 5 \mathrm{bp}>1000 \mathrm{bp}$. Since binning starting at a single window frame may cause OTU separated by $1 \mathrm{bp}$ to fall into different windows, we binned 10 times, each time beginning the bin window frame at $+1 \mathrm{bp}$. The Whittaker and Sorenson's index were calculated for all pairwise comparisons in all 10 window frames. Since binning implies homogeneous variance in similarity between 2 random assemblages, we used the maximum similarity in all pairwise samples, which is analagous to statistical treatment of data examining variance in 2 samples (Hewson \& Fuhrman 2006). Cluster analysis was conducted with the XLStat (AddinSoft SARL) program using the Whittaker Index and clustering via unweighted pair-group-mean average method (UPGMA) (Sokal \& Rohlf 1995).

\section{RESULTS}

\section{Characteristics of sampling location}

The Amazon and Orinoco River plumes were detectable by salinity $<35$ at a total of 18 stations, while the remaining 6 stations were at $\geq 35$ and therefore presumably not within plume waters. The plume extended vertically only ca. $10 \mathrm{~m}$, with waters below having typical surface mid-gyre seawater physicochemical characteristics (Del Vecchio \& Subramaniam 2004). In contrast to surface waters, below $40 \mathrm{~m}$ there was little difference in physical parameters between sites at the same depths. Bacterial production was highest at the surface $\left(0.17\right.$ to $14.10 \times 10^{5}$ cells ml $\left.{ }^{-1} \mathrm{~d}^{-1}\right)$, representing an approximate growth rate of $0.43 \mathrm{~d}^{-1}$ in the least saline plume waters and $0.04 \mathrm{~d}^{-1}$ at oceanic salinity (Fig. 2A). Beam attenuation, which measures coloured dissolved organic materials in surface waters and suspended solid concentrations in deeper waters, was 


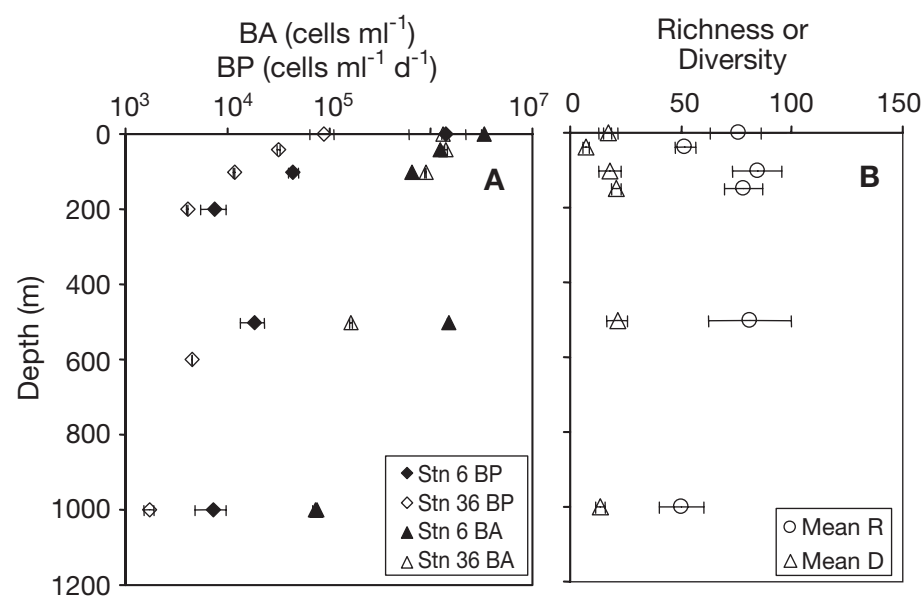

Fig. 2. Biological characteristics of stations in the North Atlantic. (A) Bacterial abundance (BA) as measured by SYBR Green at Stns 6 and 36, and bacterial production measured by ${ }^{3}$ H-leucine uptake (Simon \& Azam 1989); and (B) bacterial ARISA fingerprint richness (R) and diversity (D, Simpson's Reciprocal Index) ( \pm SE) calculated for all stations

highest in the plume waters $(67 \%)$ and lowest in oceanic waters $(5 \%)$. Furthermore, surface waters within the plume had low salinity $(<35)$ and were distinguished from oceanic waters because they had beam attenuations of $>10 \%$. At $40 \mathrm{~m}$, bacteria had slower growth rates than at the surface $\left(0.01\right.$ to $\left.0.07 \mathrm{~d}^{-1}\right)$. In contrast to surface samples, those in deeper waters (>150 m) had growth rates of 0.002 to $0.07 \mathrm{~d}^{-1}$ and had similar temperature and salinity values at all locations.

\section{Bacterioplankton assemblage characteristics}

Assemblage fingerprints contained $69 \pm 4$ (mean \pm SE) OTUs and Simpson's Reciprocal Indices of $15.4 \pm$ 1.2, but were variable with depth (Fig. 2B). Fingerprint richness and diversity were highest at the surface and from 100 to $500 \mathrm{~m}$, and were lower at 40 and $1000 \mathrm{~m}$. There was no significant difference between surface assemblage fingerprint richness and diversity in plume (salinity $=26$ to 32 ), intermediate plume (salinity 32 to 35 ) and oceanic (salinity $\geq 35$ ) conditions. Fingerprint diversity was significantly correlated in surface waters (0 to $40 \mathrm{~m}$ ) to bacterioplankton production (Table 1), which in turn was significantly correlated to salinity. Within surface waters only (not $40 \mathrm{~m}$ ), the regression between salinity and fingerprint diversity was also significant $(p<0.05)$ (Fig. 3). In surface waters there was no consistent pattern between assemblage similarity and increasing salinity (Fig. 4). Fingerprints generated from DNA collected from surface water shared Whittaker Indices of 0.22 to 0.79 , while those from 100 to $150 \mathrm{~m}$ shared Whittaker Indices of 0.32 to 0.81 (Fig. 4).
Table 1. Correlation coefficients (r) between measured bacterial parameters and salinity across all 32 samples at depths 0 to $40 \mathrm{~m}$. Significant coefficients $(\mathrm{p}<0.05, \mathrm{n}=65$, Fisher's $F$-test). Bacterial production (BP) was measured by ${ }^{3} \mathrm{H}$ leucine incorporation (Simon \& Azam 1989). Fingerprint richness was the total number of ARISA fragments, while fingerprint diversity ( $D=$ Simpson's Reciprocal Index $)$ was calculated using descriptions in Legendre \& Legendre (1998).

$$
{ }^{* *} \mathrm{p}<0.01,{ }^{* * *} \mathrm{p}<0.001
$$

\begin{tabular}{|lcccc|}
\hline & Salinity & BP & Richness & $D$ \\
\hline Salinity & \multirow{2}{*}{1.000} & $-0.805^{* * *}$ & -0.116 & $-0.453^{* *}$ \\
BP & & 1.000 & $0.518^{* *}$ & $0.735^{* * *}$ \\
Richness & & & 1.000 & $0.789^{* * *}$ \\
$D$ & & & & 1.00 \\
\hline
\end{tabular}

\section{Relationship of assemblages to environmental variables}

Fingerprint richness significantly correlated with bacterial production and diversity with both bacterial production and salinity (Table 1 ). The relative DNA fluorescence of 4 OTUs was significantly $(\mathrm{p}<0.0004$, df $=23 ; \mathrm{p}$ value $=0.05 / \#$ correlates $=0.5 / 113$; used to correct for possible Type II errors in correlation analysis) and positively correlated with beam attenuation, while 4 OTUs were significantly $(\mathrm{p}<0.0004$, $\mathrm{df}=22$ ) and positively correlated to bacterioplankton production (Table 2). A further 10 OTUs significantly ( $p<0.0004$,

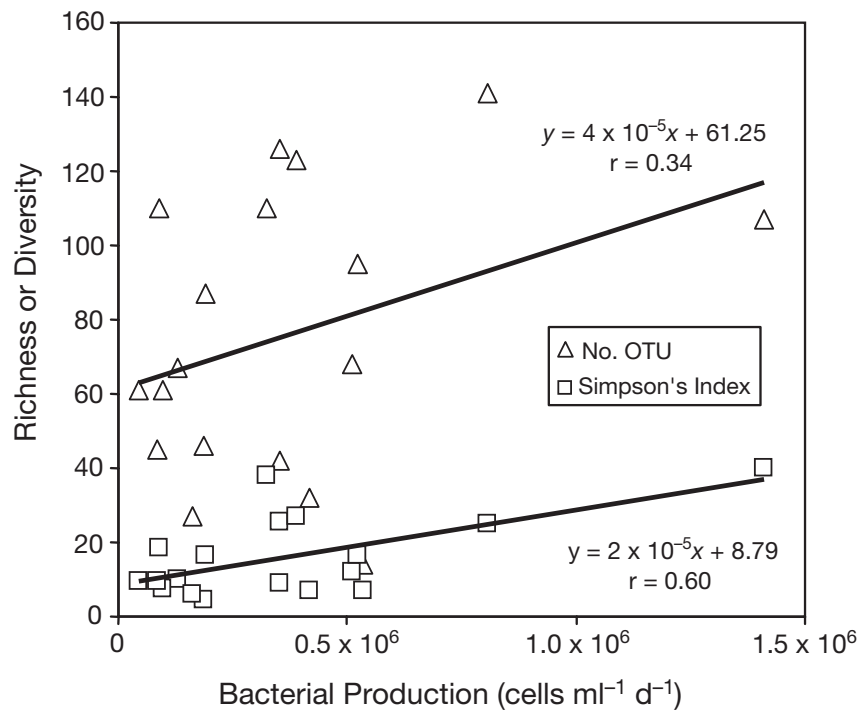

Fig. 3. Correlation between bacterioplankton production, as measured by ${ }^{3} \mathrm{H}$-leucine uptake (Kirchman et al. 1985, Simon \& Azam 1989), and the richness (No. OTU, operational taxonomic units) and diversity (Simpson's Reciprocal Index) of surface water $(0 \mathrm{~m})$ assemblage ARISA fingerprints. Note that when bacterial production data are log transformed, only the regression to diversity remains significant $(r=0.30, p>0.05$ and $\mathrm{r}=0.51, \mathrm{p}<0.01$ for richness and diversity, respectively) 
$\mathrm{df}=22$ ) correlated with the Simpson's Reciprocal Index of fingerprints, and 3 OTUs to fingerprint richness.

A number of common OTUs (i.e. those comprising $>1 \%$ of total amplified DNA fluorescence) demon- strated heterogeneity between plume $(<32)$, intermediate plume (32 to 35) and oceanic ( $>35$ ) waters (Fig. 5). A total of 11 OTUs were mainly in lowersalinity fingerprints than more oceanic fingerprints,

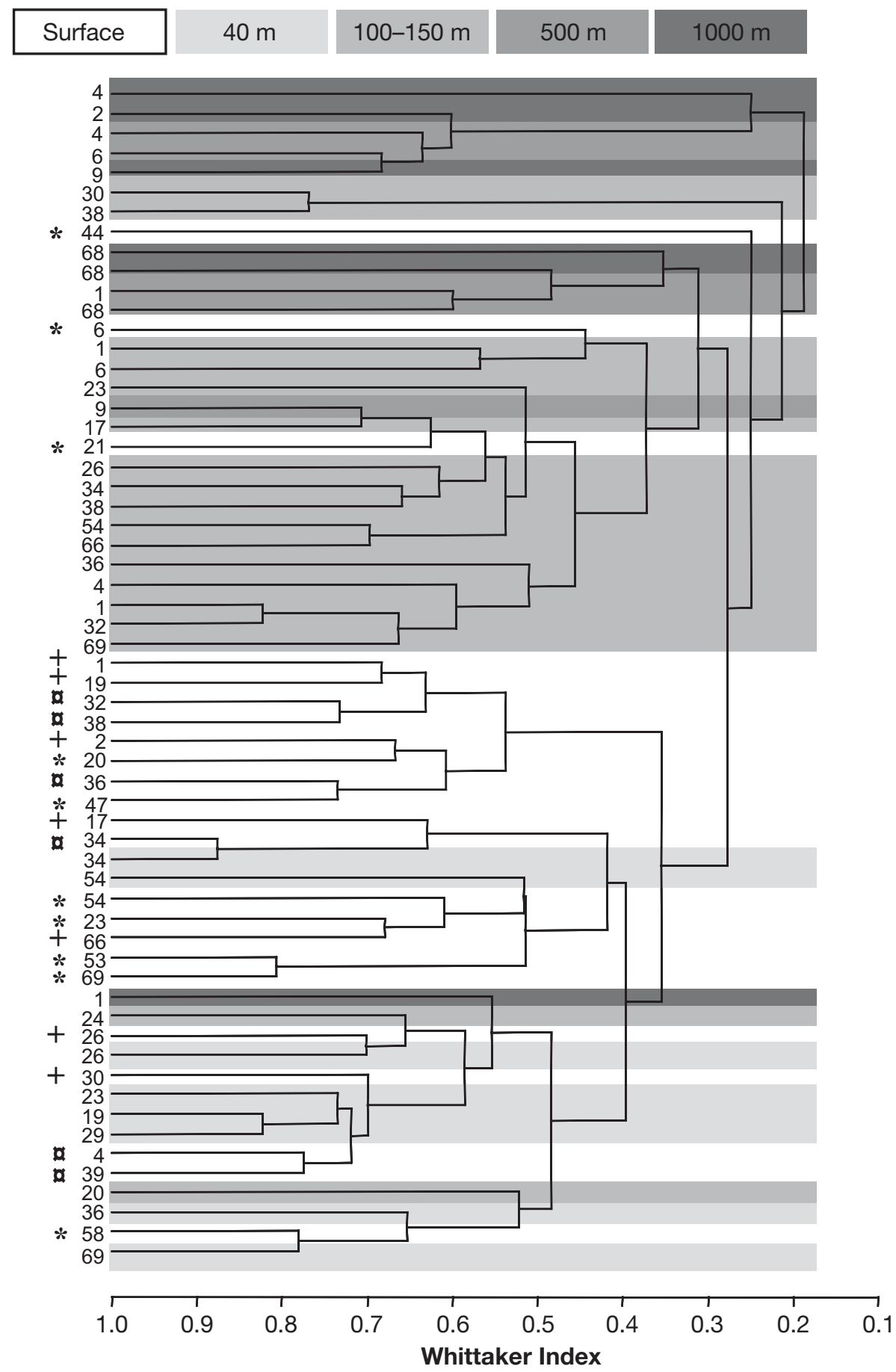

Fig. 4. Cluster analysis of assemblage ARISA patterns from samples collected at all depths and stations. Clustering using the Whittaker Index of association (Whittaker 1952) was performed by Unweighted Pair-Group-Mean Average (Sokal \& Rohlf 1995). *: surface waters which were at salinities $<32$; +: intermediate salinity (32 to 35$)$; oceanic salinity samples ( $\geq 35$ ). Station number is given on the left-hand side, while depth is indicated by the grey shading 
Table 2. Pearson's correlation coefficients between the relative proportion of total amplified DNA of each OTU (operational taxonomic unit) and microbial diversity and productivity, and beam attenuation. Only significant values $(\mathrm{p}<$ 0.0004 , where $\mathrm{p}$-value was determined by dividing 0.05 by the number of correlates [113], which avoids Type II errors in multiple correlation analysis; Sokal \& Rohlf 1995) are shown here, but the complete analysis was on all OTU relative proportions and all measured physicochemical parameters. The putative identifications of OTU are based upon 16S to 23S rRNA clone libraries from the San Pedro Ocean Time Series (SPOTS) station (Brown et al. 2005) and hence may not correspond exactly to taxa present in the west tropical Atlantic. Note that there were no significant negative correlation coefficients, which is possibly a consequence of intense gradients in bacterial productivity and beam attenuation. $D=$ Simpson's Reciprocal Diversity Index

\begin{tabular}{|llcccc|}
\hline $\begin{array}{l}\text { OTU Bin } \\
\text { (bp) }\end{array}$ & $\begin{array}{l}\text { Putative } \\
\text { identification }\end{array}$ & $D$ & $\begin{array}{l}\text { No. } \\
\text { OTU }\end{array}$ & BP & $\begin{array}{c}\text { Beam } \\
\text { attenuation }\end{array}$ \\
\hline $427-429$ & Actinobacteria & 0.72 & - & - & - \\
$433-435$ & Actinobacteria & 0.70 & - & - & - \\
$436-438$ & - & 0.78 & - & - & - \\
$442-444$ & SAR-86 & 0.74 & - & - & 0.69 \\
$457-459$ & - & 0.77 & - & - & - \\
$460-462$ & SAR-86 & - & 0.69 & - & - \\
$481-483$ & - & 0.70 & - & 0.82 & 0.69 \\
$490-492$ & - & 0.71 & - & - & - \\
$493-495$ & - & 0.78 & - & - & - \\
$496-498$ & - & - & - & 0.83 & 0.71 \\
$505-507$ & - & 0.86 & - & - & - \\
$511-513$ & - & - & - & - & 0.73 \\
$514-516$ & - & 0.88 & 0.68 & - & - \\
$517-519$ & - & - & - & 0.72 & - \\
$670-672$ & SAR-11/ & - & - & 0.72 & - \\
$725-729$ & CFB & - & 0.75 & - & - \\
\hline
\end{tabular}

while 13 OTUs comprised a greater proportion of fingerprint DNA fluorescence in oceanic fingerprints than in plume fingerprints.

\section{DISCUSSION}

Our results indicate that bacterioplankton may be strongly influenced by inputs from the Amazon and Orinoco offshore river plume. Bacterioplankton assemblage composition in plume and adjacent waters does not correspond consistently to gradients in assemblage productivity, nor to physicochemical conditions, yet measures of their diversity correlate with both. These results therefore suggest that other factors (e.g. interspecific interactions, or those between bacteria and bacterivores or viruses) may ultimately influence the relative abundance of taxa within assemblages. However, the presence of several OTUs, the distribution of which were related to different environmental settings (plume, intermediate plume and oceanic conditions), suggests that mixing of assemblages from water masses may cause the spatial patchiness in bacterioplankton assemblage composition. Finally, our results demonstrate that while allochthonous inputs in surface water plumes may strongly influence the composition and productivity of bacterioplankton assemblages immediately below plume waters within the euphotic zone, they do not strongly affect assemblage composition below the euphotic zone.

\section{Potential errors associated with ARISA fingerprints}

Like all PCR based techniques, ARISA fingerprinting may be influenced by biases caused potentially by uneven amplification efficiencies due to sequence heterogeneity (Suzuki \& Giovannoni 1996, Polz \& Cavanaugh 1998, Suzuki et al. 1998), intertaxon operon copy number differences (Crosby \& Criddle 2003), differential extractability of cells in communities (Polz et al. 1999), or differences in the amount of DNA per cell. Given the slow bacterial growth rates observed during this study, representing growth rates of 0.04 to $0.43 \mathrm{~d}^{-1}$ across all salinities, we expect the bacteria to contain only 1 or 2 copies of the rrn operon (Klappenbach et al. 2000). A recent study by Brown et al. (2005) demonstrated a strong correlation $\left(\mathrm{r}^{2}=0.86\right)$ over $4 \mathrm{yr}$ of time series data between the relative fluorescence of an OTU corresponding to Prochlorococcus and estimates of abundance of this picophytoplankter by flow cytometry. Furthermore, another study of the mcrA gene by TRFLP indicated correlations between template quantity and TRF relative fluorescence (Leuders \& Friedrich 2003), which is consistent with a study demonstrating that kinetic biases in PCR are small (Suzuki et al. 1998).

\section{Effects of Amazon plume on assemblage productivity and diversity}

Our results demonstrate that low-salinity waters have higher bacterial production rates than nonplume waters. Enhanced productivity also positively influenced the diversity (i.e. total number of taxa and rank distribution) of bacterioplankton assemblages; however, the composition of these assemblages is not consistent between locations within plume waters. Low-salinity water plumes contain high concentrations of labile DOC and that produced by elevated 


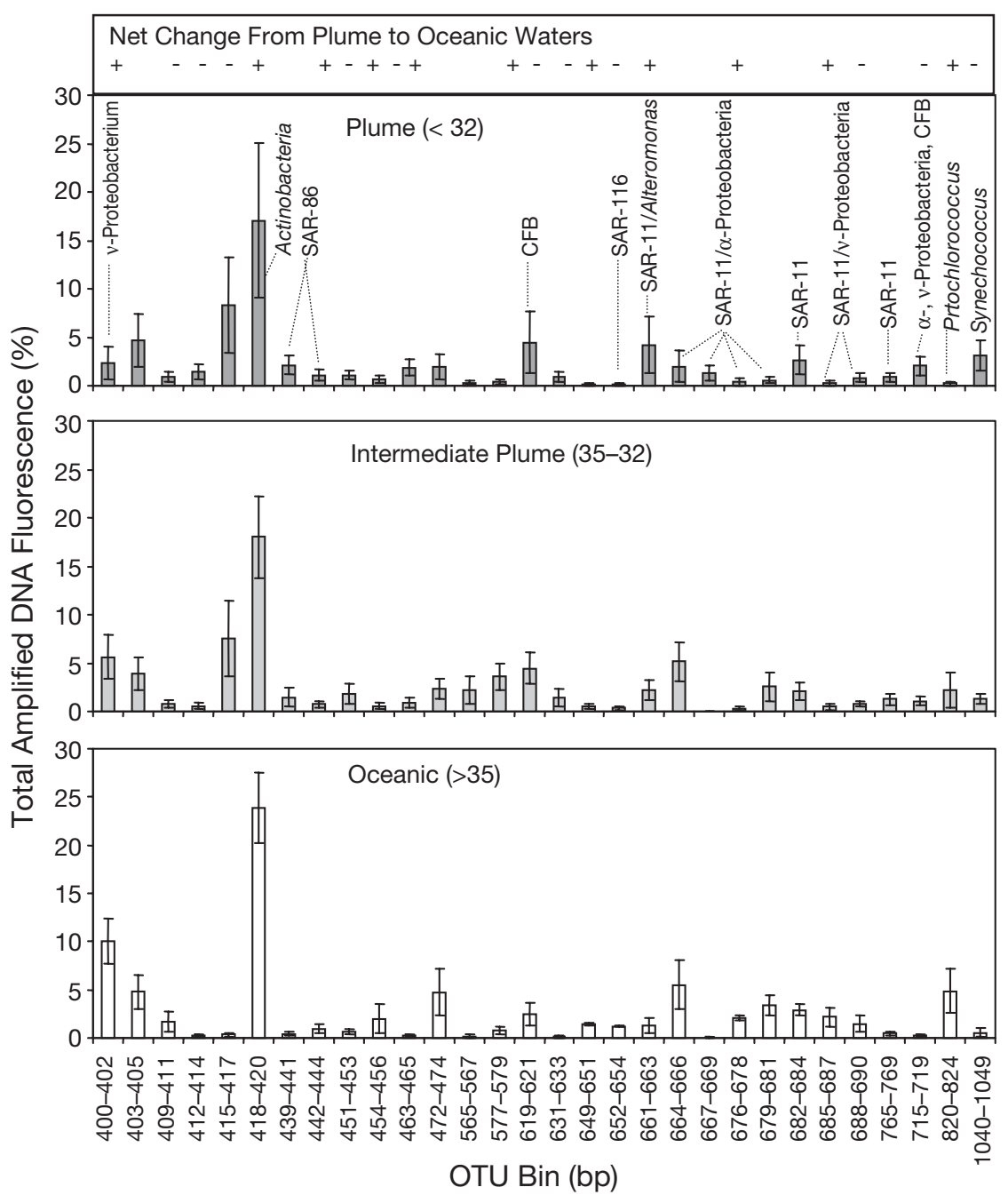

Fig. 5. Contribution to total amplified DNA fluorescence of common (i.e. $>1 \%$ of DNA fluorescence) OTU in different environmental settings: plume (salinity <32), intermediate plume (32 to 35 ) and oceanic ( $>35$ ) waters. Putative identifications are based upon a $16 \mathrm{~S}$ to $23 \mathrm{~S}$ rRNA database from the San Pedro Ocean Time Series (SPOTS) station (Brown et al. 2005). Change in relative proportion of each OTU bin when moving from plume to oceanic waters shown (i.e. -: an OTU is more common in plume waters than in oceanic waters; +: an OTU is more common in oceanic waters than in plume waters). Error bars $= \pm \mathrm{SE}$

primary production in plume waters (Amon \& Benner 1996a, 1998). DOC is the primary nutrition of heterotrophic bacterioplankton; hence, it is not surprising that bacterioplankton production was significantly and negatively correlated to salinity. Similar influences of offshore low-salinity waters upon bacterioplankton production have been observed in the Mississippi River plume (Amon \& Benner 1998, Jochem 2003).

The significant and positive correlation between surface bacterioplankton fingerprint diversity and bacterioplankton production may reflect ecological niche availability. Several relationships between productivity and diversity of organisms have been observed in previous studies. Linear increases in diversity with primary productivity have been reported in both animal and plant communities (Currie 1991, Waide 1999, Buckling et al. 2000, Kassen et al. 2000). However, non-linear, unimodal, relationships between diversity and productivity have also been observed, related in part to disturbance. Morphological diversity in cultures of Pseudomonas fluorescens is greatest at intermediate productivity when incubations are disturbed (shaken) (Kassen et al. 2000). Under in situ conditions, the unimodal interaction between disturbance and diversity may be due to alleviation of resource competition (Janzen 1970, Connell 1978, Givnish 1999, Buckling et al. 2000), the inflection points of which may be shifted when disturbance and resource availability occur along similar gradients (Buckling et al. 2000, Kondoh 2001). Under stable conditions, at least one study has reported little relationship between productivity and diversity under non-stressed conditions, yet the relationship became unimodal when stressed (Mulder et al. 2001). This result was possibly a consequence of intertaxonomic facilitation (Mulder et al. 2001, Cardinale et al. 2002). Since higher bacterioplankton production results from higher resource availability when not constrained by temperature or pressure (Hansell \& Ducklow 2003), allochthonous inputs may support the growth of a larger variety of bacterioplankton OTU by reducing interspecific resource competition (Torsvik et al. 2002). DOC inputs probably also comprise a highly complex suite of compounds. Hence, it is conceivable that bacterioplankton diversity patterns reflect changes in DOC composition as more labile compounds are removed from the plume as it is advected offshore (Amon \& Benner 1996a,b, 1998). Our results contrast with previous studies of bacterioplankton productivity relationships with diversity in mesocosms (HornerDevine et al. 2003), which found no overall impact of primary production (chl a) upon richness of assemblages, but non-linear relationships between the relative abundance of individual phylotypes and productivity. 


\section{Effects of river plume on bacterioplankton assemblage composition}

Comparison of surface water samples at various salinities indicated no consistent effect of decreased salinity upon assemblage composition. In another analysis of bacterioplankton assemblages from this region, there was a non-linear decrease in pairwise similarity between assemblages and their separation distance, suggesting that factors causing changes in assemblage composition were localised at scales $<50 \mathrm{~km}$ (Hewson et al. 2006). However, several common (>1\% total amplified DNA fluorescence) OTUs had distinct distributions in each environmental setting. This suggests that the relative abundances of some bacterial OTUs were specific to plume conditions. However changes in rarer OTUs (i.e. those comprising $<1 \%$ of total amplified DNA fluorescence) caused inconsistency in composition along salinity gradients. Putative identifications of OTUs that corresponded to different environment types were made from a $16 \mathrm{~S}$ to $23 \mathrm{~S}$ rRNA clone library database prepared from the San Pedro Ocean Time Series (SPOTS) station (Brown et al. 2005), and hence may not correspond exactly to taxa present in the west tropical Atlantic (Fig. 5). We feel this approach is reasonable for the groups named in this study, since ITS lengthsin an online ITS data repository (http:// miracle.umh.es/rissc/index.html) of marine representatives from other geographic locations are coherent with those from the SPOTS station. Of OTUs that comprised a higher proportion of oceanic fingerprint DNA fluorescence, most have been found in high abundance in marine environments by various enumeration techniques, and also comprised a large component of open-ocean 16S rRNA clone libraries. For example, the SAR-11 group has been demonstrated to have high abundance by fluorescence in situ hybridization counts in most pelagic samples (Morris et al. 2002). Similarly, the Prochlorococcus, SAR-116 and Actinobacteria groups have been described, in addition to SAR-11, as common components of $16 \mathrm{~S}$ rRNA clone libraries (Fuhrman \& Ouverney 1998, Giovannoni \& Rappe 2000). OTUs that comprised a greater proportion of total amplified DNA fluorescence in plume fingerprints mostly did not correspond to taxa within the $16 \mathrm{~S}$ to $23 \mathrm{~S}$ rRNA database with the notable exception of Synechococcus. It is interesting to note that across the comparison between plume and oceanic samples, the Prochlorococcus and Synechococcus OTU had inverse distributions (more Prochlorococcus in ocean than in plume waters, and more Synechococcus in plume than in oceanic waters). Note that neither Prochlorococcus or Synechococcus OTUs had significant correlations to richness, diversity, bacterial pro- duction or beam attenuation. Similar phylotype habitat specificity along estuarine gradients has been reported (Crump et al. 1999, Troussellier et al. 2002, Stepanauskas et al. 2003, Hewson \& Fuhrman 2004). While we cannot exclude the possibility that some of the variability between assemblages may be due to elapsed time between samples (approx. $5 \mathrm{wk}$ in our case), at least 1 study in moderately productive waters (similar to those in the Amazon offshore river plume) demonstrated few changes in composition over 3 mo of sampling (Riemann \& Middelboe 2002).

\section{Influence of plume waters on subsurface bacterial assemblages}

Our data indicate that riverine waters have a significant impact upon the diversity and composition of bacterioplankton assemblages immediately below the plume (i.e. at $40 \mathrm{~m}$ ); however, these effects are not evident in deeper waters $(>100 \mathrm{~m})$. At the least saline Stn 6 , light was attenuated $83 \%$ at $40 \mathrm{~m}$, while at the most oceanic station light was only attenuated $23 \%$ at the same depth, indicating that the plume exerts potentially strong light limitation upon sub-plume waters. We hypothesized that in oceanic waters, assemblages would be more similar to each other at 0 and $40 \mathrm{~m}$ than within the plume, where salinity gradients prevent mixing and where distinct communities may form in low-salinity and oceanic-salinity water masses in the plume and beneath it, respectively. Fingerprint richness and diversity were lowest immediately below plume waters at $40 \mathrm{~m}$; however, there were no consistent effects of the plume on the similarity between plume and $40 \mathrm{~m}$ bacterioplankton fingerprints. Rather, our data suggest that the most saline (and consequently oceanic) bacterial communities at 0 and $40 \mathrm{~m}$ had the greatest dissimilarity (e.g. Stn 34 and Stn 36). These data suggest that the presence of strong vertical stratification in pelagic autotrophic communities may have stronger impacts upon bacterioplankton assemblage composition than the influence of low-salinity surface water plumes.

The lower richness and diversity of immediate subplume water bacterioplankton fingerprints may be due to light limitation of autotrophic bacterioplankton, or nutrient limitation of all bacterioplankton. Interestingly, OTUs corresponding tentatively to 2 biogeochemically important autotrophic bacterioplankters (Prochlorococcus and Synechococcus) have significantly lower ( $\mathrm{p}<0.05$, Student's $t$-test, $\mathrm{n}=6$ ) relative contribution to total DNA fluorescence in fingerprints beneath low-salinity plumes than at oceanic stations, suggesting that these organisms were limited by light availability. A strong salinity gradient between plume 
and sub-plume waters may restrict diffusion or mixing of nutrients. As a consequence, sub-plume waters may contain limited niches for bacteria, which is reflected in lower assemblage fingerprint richness and diversity. While bacterial abundance and production did not have subsurface minima similar to fingerprint diversity and richness, there was a steep decline in these values from surface to $40 \mathrm{~m}$ samples.

Beneath the surface mixed layer, bacterioplankton assemblage fingerprints were highly stratified by depth, with more similar assemblages at the same depth nearby than to deeper or shallower assemblages at the same station (Fig. 4). Similar stratification of communities has been noted in other oligotrophic marine environments (Moeseneder et al. 2001, Troussellier et al. 2002) and indicates that assemblages are distinctive to habitat. We expected that assemblages would be more spatially homogeneous at deeper depths (i.e 100 to $150 \mathrm{~m}$ ) since environmental conditions were more homogeneous (containing similar temperature and salinity values), than shallower waters which had more variable physicochemical characteristics. However, variability in assemblage composition between sampling locations was greater at depths between 100 and $150 \mathrm{~m}$ (mean Whittaker Index $=0.47 \pm 0.01, \mathrm{n}=16$ ), than at the surface (mean Whittaker Index $=0.41 \pm 0.01, \mathrm{n}=32$ ). This deep water variability suggests that bacterial assemblages within this environment may be influenced by inputs from overlying waters, where inputs from the river plume are variable because of the presence of patchy water masses with variable productivity.

\section{CONCLUSIONS}

Our results demonstrate that the Amazon and Orinoco River plumes, which are the dominant allochthonous resource inputs into the North Atlantic, have significant effects upon bacterioplankton assemblages in these waters. These results agree with our hypothesis that assemblage composition is correlated to production since factors affecting the growth rate of bacterioplankton are selective for some taxa. Bacterioplankton assemblages may contain taxa selected for by environmental conditions related to their habitat (i.e. the presence of river water). The interplay between resource availability and selective loss mechanisms is argued to strongly affect total richness and diversity of bacterioplankton assemblages (Fuhrman 1992, Torsvik et al. 2002). Consequently, low-salinity waters, which carry with them high concentrations of labile DOC (Aucour et al. 2003), may indirectly effect the total assemblage diversity but do not give rise to uniform communities. Finally, this study raises interesting questions about the relationship between resource complexity and species composition of bacterioplankton composition, especially considering a large fraction of available resources are as yet uncharacterized.

Acknowledgements. The authors gratefully acknowledge the assistance of the crew of the RV 'Seward Johnson', C. Mahaffey, P. J. Morris, T. Gunderson, E. J. Carpenter, A. Subramaniam, T. Meador, R. Foster and R. Del Vecchio on the cruise and R. Beinart, M. S. Schwalbach, X. Liang and X. Hernandez for assistance with lab analyses. SeaWiFS data courtesy of the NASA SeaWiFS project and Orbital Image Sciences Corporation. This work was supported by NSF grants MCB0084231 awarded to J.A.F. and D. Caron, OCE0527034 awarded to J.A.F., D.G.C. and V. Coles, and grants OCE9981545 and OCE9981371 awarded to D.G.C., E. Carpenter, A. Michaels and A. Subramaniam. This work is in partial fulfilment of a PhD by I.H.

\section{LITERATURE CITED}

Acinas SG, Rodriguez-Valera F, Pedrós-Alió C (1997) Spatial and temporal variation in marine bacterioplankton diversity as shown by RFLP fingerprinting of PCR amplified 16S rDNA. FEMS Microbiol Ecol 24:27-40

Acinas SG, Klepac-Ceraj V, Hunt DE, Pharino C, Ceraj I, Distel DL, Polz MF (2004) Fine-scale phylogenetic architecture of a complex bacterial community. Nature 430: 551-554

Amon RMW, Benner R (1996a) Bacterial utilization of different size classes of dissolved organic matter. Limnol Oceanogr 41:41-51

Amon RMW, Benner R (1996b) Photochemical and microbial consumption of dissolved organic carbon and dissolved oxygen in the Amazon River system. Geochim Cosmochim Acta 60:1783-1792

Amon RMW, Benner R (1998) Seasonal patterns of bacterial abundance and production in the Mississippi River plume and their importance for the fate of enhanced primary production. Microb Ecol 35:289-300

Aucour AM, Tao FX, Moreira-Turcq P, Seyler P, Sheppard S, Benedetti MF (2003) The Amazon River: behavior of metals ( $\mathrm{Fe}, \mathrm{Al}, \mathrm{Mn})$ and dissolved organic matter in the initial mixing at the Rio Negros/Solimoes confluence. Chem Geol 197:271-285

Avaniss-Aghajani E, Jones K, Chapman D, Brunk C (1994) A molecular technique for identification of bacteria using small subunit ribosomal RNA sequences. Biotechniques 17:144-149

Azam F (1998) Microbial control of oceanic carbon flux: the plot thickens. Science 280:694

Azam F, Fenchel T, Field JG, Gray JS, Meyer-Reil LA, Thingstad F (1983) The ecological role of water-column microbes in the sea. Mar Ecol Prog Ser 10:257-263

Beja O, Aravind L, Koonin EV, Suzuki MT and 8 others (2000) Bacterial rhodopsin: evidence for a new type of phototrophy in the sea. Science 289:1902-1906

Brown MV, Schwalbach MS, Hewson I, Fuhrman JA (2005) Coupling 16S-ITS rDNA clone libraries and ARISA to show marine microbial diversity: development and application to a time series. Environ Microbiol 7:1466-1479

Buckling A, Kassen R, Bell G, Rainey PB (2000) Disturbance and diversity in experimental microcosms. Nature 408: 961-964 
Cardinale BJ, Palmer MA, Collins SL (2002) Species diversity enhances ecosystem functioning through interspecific facilitation. Nature 415:426-429

Choi KH, Dobbs FC, Cowen RK (2001) Short-term temporal and spatial dynamics of bacterioplankton near Barbados in the Caribbean Sea. Aquat Microb Ecol 25:43-53

Connell JH (1978) Diversity in tropical rainforests and coral reefs. Science 199:1304-1310

Crosby LD, Criddle CS (2003) Understanding bias in microbial community analysis techniques due to $\mathrm{rrn}$ operon copy number heterogeneity. Biotechniques 34:790-802

Crump BC, Amrmbrust EV, Baross JA (1999) Phylogenetic analysis of particle-attached and free-living bacterial communities in the Columbia River, its estuary and the adjacent coastal ocean. Appl Environ Microbiol 65:3192-3204

Currie DJ (1991) Energy and large-scale patterns of animaland plant-species richness. Am Nat 137:27-49

De Long EF (2002) Microbial population genomics and ecology. Curr Opin Microbiol 5:520-524

Del Vecchio R, Subramaniam A (2004) Influence of the Amazon River on the surface optical properties of the western tropical North Atlantic Ocean. J Geophys Res 109: C11001, doi:11010.11029/12004JC002503

DeMaster DJ, Smith WO Jr, Nelson DM, Aller JY (1996) Biogeochemical processes in Amazon shelf waters: chemical distributions and uptake rates of silicon, carbon and nitrogen. Coast Shelf Res 16:617-643

Farjalla VF, Esteves FA, Bozelli RL, Roland F (2002) Nutrient limitation of bacterial production in clear water Amazonian ecosystems. Hydrobiol 489:197-205

Fisher MM, Triplett EW (1999) Automated approach for ribosomal intergenic spacer analysis of microbial diversity and its application to freshwater bacterial communities. Appl Environ Microbiol 65:4630-4836

Flagg CN, Gordon RL, McDowell S (1986) Hydrographic and current observations on the continental slope and shelf in the Western Equatorial Atlantic. J Phys Oceanogr 16: $1412-1429$

Fuhrman JA (1992) Bacterioplankton roles in cycling of organic matter: The Microbial food web. In: Falkowski PG, Woodhead AD (eds) Primary productivity and Biogeochemical Cycles in the Sea. Plenum Press, New York

Fuhrman JA, Azam F (1980) Bacterioplankton secondary production estimates for coastal waters of British Columbia, Antarctica, and California. Appl Environ Microbiol 39: 1085-1095

Fuhrman JA, Azam F (1982) Thymidine incorporation as a measure of heterotrophic bacterioplankton production in marine surface waters: Evaluation and field results. Mar Biol 66:109

Fuhrman JA, Ouverney CC (1998) Marine microbial diversity studied via 16S rRNA sequences: cloning results from coastal waters and counting of native archaea with fluorescent single cell probes. Aquat Ecol 32:3-15

Fuhrman JA, Suttle CA (1993) Viruses in marine planktonic systems. Oceanogr 6:51-63

Fuhrman JA, Comeau DE, Hagström ^, Chan AM (1988) Extraction of DNA suitable for molecular biological studies from natural planktonic microorganisms. Appl Environ Microbiol 54:1426-1429

Fuhrman JA, Sleeter TD, Carlson CA, Proctor LM (1989) Dominance of bacterial biomass in the sargasso sea and its ecological implications. Mar Ecol Prog Ser 57:207-217

Fuhrman JA, McCallum K, Davis AA (1992) Novel major archaebacterial group from marine plankton. Nature 356 : 148-149

Giovannoni SJ, Rappe M (2000) Evolution, diversity and mol- ecular ecology of marine prokaryotes. In: Kirchman DL (ed) Microbial Ecology of the Oceans. Wiley-Liss, New York, p 47-84

Giovannoni SJ, Britschgi TB, Moyer CL, Field KG (1990) Genetic diversity in Sargasso Sea bacterioplankton. Nature 345:60-63

Givnish TJ (1999) On the causes of gradients in tropical tree diversity. J Ecol 87:193-210

Goni GJ, Johns WE (2001) A census of North Brazil Current rings observed from TOPEX/POSEIDON altimetry: 1992-1998. Geophys Res Lett 28:1-4

Hansell DA, Ducklow HW (2003) Bacterioplankton distribution and production in the bathypelagic ocean: Directly coupled to particulate organic carbon export? Limnol Oceanogr 48:150-156

Hellweger FL, Gordon AL (2002) Tracing Amazon River water into the Caribbean Sea. J Mar Res 60:537-549

Hewson I, Fuhrman JA (2004) Bacterioplankton species richness and diversity along an estuarine gradient in Moreton Bay, Australia. Appl Environ Microbiol 70:3425-3433

Hewson I, Fuhrman JA (2006) Improved strategy for comparing microbial assemblage fingerprints. Microb Ecol 51: 147-153

Hewson I, Vargo GA, Fuhrman JA (2003) Bacterial diversity in shallow oligotrophic marine benthos and overlying waters: effects of virus infection, containment and nutrient enrichment. Microb Ecol 46:322-336

Hewson I, Steele JA, Capone DG, Fuhrman JA (2006) Temporal and spatial scales of variation in bacterioplankton assemblages of oligotrophic surface waters. Mar Ecol Prog Ser 311:67-77

Hollibaugh JT, Wong PS, Murrell MC (2000) Similarity of particle-associated and free-living bacterial communities in northern San Francisco Bay, California. Aquat Microb Ecol 21:103-109

Horner-Devine MC, Leibold MA, Smith VH, Bohannan BJM (2003) Bacterial diversity patterns along a gradient of primary productivity. Ecol Lett 6:613-622

Janzen DH (1970) Herbivores and the number of tree species in tropical forests. Am Nat 104:501-528

Jochem FJ (2003) Photo- and heterotrophic pico- and nanoplankton in the Mississippi River plume: distribution and grazing activity. J Plankton Res 25:1201-1214

Kassen R, Buckling A, Bell G, Rainey PB (2000) Diversity peaks at intermediate productivity in a laboratory microcosm. Nature 406:508-512

Kirchman D, Knees E, Hodson R (1985) Leucine incorporation and its potential as a measure of protein-synthesis by bacteria in natural aquatic systems. Appl Environ Microbiol 49:599-607

Klappenbach JL, Dunbar JM, Schmidt TM (2000) rRNA operon copy number reflects ecological strategies of bacteria. Appl Environ Microbiol 66:1328-1333

Kolber ZS, Plumley FG, Lang AS, Beatty JT and 6 others (2001) Contribution of aerobic photoheterotrophic bacteria to the carbon cycle in the ocean. Science 292: 2492-2495

Kondoh M (2001) Unifying the relationships of species richness to productivity and disturbance. Proc R Soc Lond B Biol Sci 268:269-271

Kuypers MMM, Lavik G, Woebken D, Schmid M, Fuchs BM, Amann R, Jorgensen BB, Jetten MSM (2005) Massive nitrogen loss from the Benguela upwelling system through anaerobic ammonium oxidation. Proc Natl Acad Sci USA 102:6478-6483

Legendre P, Legendre L (1998) Numerical ecology. Elsevier, Amsterdam 
Lerman A (1980) Controls on river water composition and mass balance of river systems. In: Martin JM (ed) River inputs to ocean systems. Wiley \& Sons, Chichester, p 1-4

Leuders T, Friedrich MW (2003) Evaluation of PCR amplification bias by terminal restriction fragment length polymorphism analysis of small-subunit rRNA and mcrA genes by using defined template mixtures of methanogenic pure cultures and soil DNA extracts. Appl Environ Microbiol 69:320-326

Long RA, Azam F (2001) Antagonistic interactions among marine pelagic bacteria. Appl Environ Microbiol 67: 4975-4983

Moeseneder MM, Winter C, Herndl GJ (2001) Horizontal and vertical complexity of attached and free-living bacteria of the eastern Mediterranean Sea, determined by $16 \mathrm{~S}$ rDNA and 16S rRNA fingerprints. Limnol Oceanogr 46:95-107

Morris RM, Rappé M, Connon SA, Vergin KL, Siebold WA, Carlson CA, Giovannoni SJ (2002) SAR11 clade dominated ocean surface bacterioplankton communities. Nature 420:806-810

Mulder CPH, Uliassi DD, Doak DF (2001) Physical stress and diversity-productivity relationships: the role of positive interactions. Proc Natl Acad Sci USA 98:6704-6708

Nittrouer CA, DeMaster DJ (1996) The Amazon shelf setting: tropical, energetic, and influenced by a large river. Cont Shelf Res 16:553-573

Noble RT, Fuhrman JA (1998) Use of SYBR Green I rapid epifluoresence counts of marine viruses and bacteria. Aquat Microb Ecol 14:113-118

Palenik B, Brahamsha B, Larimer FW, Land M and 11 others (2003) The genome of the motile marine Synechococcus. Nature 424:1037-1042

Polz MF, Cavanaugh CM (1998) Bias in template-to-product ratios in multitemplate PCR. Appl Environ Microbiol 64: 3724-3730

Polz MF, Harbison C, Cavanaugh CM (1999) Diversity and heterogeneity of epibiotic bacterial communities on the marine nematode Eubostrichus dianae. Appl Environ Microbiol 65:4271-4275

Riemann L, Middelboe M (2002) Stability of bacterial and viral community compositions in Danish coastal waters as depicted by DNA fingerprinting techniques. Aquat Microb Ecol 27:219-232

Ryther JH, Menzel DW, Corwin N (1967) Influence of the Amazon River outflow on the ecology of the western tropical Atlantic. J Mar Res 25:69-82

Schmidt TM, DeLong EF, Pace NR (1991) Analysis of a marine picoplankton community by $16 \mathrm{~S}$ ribosomal-RNA gene cloning and sequencing. J Bacteriol 173:4371-4378

Šimek K, Pernthaler J, Weinbauer MG, Hornák K, Dolan JR, Nedoma J, Masín M, Amann R (2001) Changes in bacter-

Editorial responsibility: Bess Ward,

Princeton, New Jersey, USA ial community composition and dynamics and viral mortality rates associated with enhanced flagellate grazing in a mesoeutrophic reservoir. Appl Environ Microbiol 67: $2723-2733$

Simon M, Azam F (1989) Protein content and protein synthesis rates of planktonic marine bacteria. Mar Ecol Prog Ser $51: 201-213$

Sokal RR, Rohlf FJ (1995) Biometry. The principles and practice of statistics in biological research. Freeman, New York

Stepanauskas R, Moran MA, Bergamaschi BA, Hollibaugh JT (2003) Covariance of bacterioplankton composition and environmental variables in a temperate delta system. Aquat Microb Ecol 31:85-98

Suzuki MT, Giovannoni SJ (1996) Bias caused by template annealing in the amplification of mixtures of 16S rRNA genes by PCR. Appl Environ Microbiol 62:625-630

Suzuki MT, Rappé M, Giovannoni SJ (1998) Kinetic bias in estimates of picoplankton community structure obtained by measurements of small-subunit rRNA gene PCR amplicon length heterogeneity. Appl Environ Microbiol 64: $4522-4529$

Thingstad TF, Lignell R (1997) A theoretical approach to the question of how trophic interactions control carbon demand, growth rate, abundance and diversity. Aquat Microb Ecol 13:19-27

Torsvik V, Ovreas L, Thingstad TF (2002) Prokaryotic diversity-magnitude, dynamics and controlling factors. Science 296:1064-1066

Troussellier M, Schafer H, Batailler N, Bernard L, and 5 others (2002) Bacterial activity and genetic richness along an estuarine gradient (Rhone River plume, France). Aquat Microb Ecol 28:13-24

Venter JC, Remington K, Heidelberg JF, Halpern AL and 19 others (2004) Environmental genome shotgun sequencing of the Sargasso Sea. Science 304:66-74

Waide R (1999) The relationship between productivity and species richness. Annu Rev Ecol Syst 30:257-300

Wawrik B, Paul JH, Campbell D, Griffin D, Houchin LA, Fuentes-Ortega A, Muller-Karger F (2003) Vertical structure of the phytoplankton community associated with a coastal plume in the Gulf of Mexico. Mar Ecol Prog Ser 251:87-101

Whittaker RH (1952) A study of summer foliage insect communities in the Great Smoky Mountains. Ecol Monogr 22: $1-44$

Zehr JP, Ward BB (2002) Nitrogen cycling in the ocean: new perspectives on processes and paradigms. Appl Environ Microbiol 68:1015-1024

Zehr JP, Carpenter EJ, Villareal TA (2000) New perspectives on nitrogen-fixing microorganisms in tropical and subtropical oceans. Trends Microbiol 8:68-73

Submitted: September 30, 2005; Accepted: January 23, 2006 Proofs received from author(s): March 7, 2006 